\title{
Natural history and population data of fishes in caves of the Serra do Ramalho karst area, Middle São Francisco basin, northeastern Brazil
}

\author{
Eleonora Trajano ${ }^{1,3}$, Sandro Secutti ${ }^{1} \&$ Maria Elina Bichuette ${ }^{2}$ \\ ${ }^{1}$ Departamento de Zoologia, Instituto de Biociências, \\ Universidade de São Paulo - USP, \\ Rua do Matão, Travessa, 14, 101, CEP 05508-900, São Paulo, SP, Brazil \\ ${ }^{2}$ Departamento de Ecologia e Biologia Evolutiva, \\ Universidade Federal de São Carlos - UFSCar, \\ Via Washington Luis, Km 235, CP 676, CEP 13565-905, São Carlos, SP, Brazil \\ ${ }^{3}$ Corresponding author: Eleonora Trajano,e-mail: etrajano@usp.br
}

TRAJANO, E., SECUTTI, S. \& BICHUETTE, M.E. Natural history and population data of fishes in caves of the Serra do Ramalho karst area, Middle São Francisco basin, northeastern Brazil. Biota Neotrop., 9(1): http://www.biotaneotropica.org.br/v9n1/en/abstract?article+bn02909012009.

\begin{abstract}
During the exploration and mapping of new caves in Serra do Ramalho karst area, southern Bahia state, cavers from the Grupo Bambuí de Pesquisas Espeleológicas - GBPE (Belo Horizonte) noticed the presence of troglomorphic catfishes (species with reduced eyes and/or melanic pigmentation), which we intensively investigated with regards to their ecology and behavior since 2005. Non-troglomorphic fishes regularly found in the studied caves were included in this investigation. We present here data on the natural history of two troglobitic (exclusively subterranean troglomorphic species) fishes - Rhamdia enfurnada Bichuette \& Trajano, 2005 (Heptapteridae; Gruna do Enfurnado) and Trichomycterus undescribed species (Trichomycteridae; Lapa dos Peixes and Gruna da Água Clara), and non-troglomorphic Hoplias cf. malabaricus, probably a troglophile (able to form populations both in epigean and subterranean habitats) in the Gruna do Enfurnado, and Pimelodella sp., a species with a sink population in the Lapa dos Peixes.
\end{abstract}

Keywords: caves, natural history, fish, troglobites, Bahia state.

TRAJANO, E., SECUTTI, S. \& BICHUETTE, M.E. História natural e dados populacionais de peixes em cavernas da área cárstica da Serra do Ramalho, sul da Bahia. Biota Neotrop., 9(1): http://www.biotaneotropica. org.br/v9n1/pt/abstract?article+bn02909012009.

Resumo: Durante a exploração e mapeamento de cavernas da área cárstica da Serra do Ramalho, sul da Bahia, espeleólogos do Grupo Bambuí de Pesquisas Espeleológicas - GBPE (Belo Horizonte) notaram a presença de peixes troglomórficos (com olhos e/ou pigmentação melânica reduzidos), que começamos a investigar intensivamente a partir de 2005. Paralelamente, levantamentos da fauna de invertebrados cavernícolas confirmaram a importância espeleofaunística dessa região. Apresentamos aqui dados sobre duas espécies de peixes troglóbios (troglomórficos exclusivamente subterrâneos) - Rhamdia enfurnada Bichuette \& Trajano, 2005 (Heptapteridae; Gruna do Enfurnado) e Trichomycterus sp. não descrita (Trichomycteridae; Lapa dos Peixes e Gruna da Água Clara). São fornecidas informações sobre peixes não troglomórficos encontrados nessas cavernas, tais como Hoplias cf. malabaricus, provavelmente troglófila (capaz de formar populações tanto em habitats epígeos como subterrâneos) na Gruna do Enfurnado, e Pimelodella sp., com grupo de migrantes ("sink population”) de média a longa permanência na Lapa dos Peixes.

Palavras-chave: cavernas, história natural, peixes, troglóbios, estado da Bahia. 


\section{Introduction}

Brazil has a remarkable subterranean ichthyofauna, similar to a few other countries or geographically comparable karst areas, such as Mexico, China and the southeastern Asia. Twenty-four species of Brazilian subterranean fishes are known to present classical troglomorphisms (specializations related to the hypogean life), i.e., reduction of eyes and pigmentation at least at some degree beyond that observed in their epigean (surface) congeners, indicating a troglobitic (exclusively subterranean) status for these fishes. The majority (all but two) are Siluriformes belonging to four out of 12 catfish families found in Brazil. These species occur in different karst areas, situated in distinct phytogeographic domains (humid Atlantic forest, savannah-like Cerrado, semiarid Caatinga) and occupying different kinds of habitat (from open channel streams, including base-level streams and vadose tributaries, to the upper phreatic zone), and also in non-karst areas in the Amazon basin, without a taxonomic correlation. In addition, several putative troglophilic fishes (species able to establish self-sustained populations both in epigean and in subterranean habitats) have also been recorded in Brazilian caves (see Mattox et al., 2008).

The population ecology of several Brazilian cave catfishes (Siluriformes) has been studied through mark-recapture methods (for the heptapterids Pimelodella kronei (Ribeiro, 1907) - Trajano 1991, and P. spelaea Trajano, Reis \& Bichuette, 2004 - Trajano et al. 2004; the trichomycterids Trichomycterus itacarambiensis Trajano \& Pinna, 1997- Trajano, 1997a, Ituglanis bambui Bichuette \& Trajano, 2004 and I. passensis Fernández \& Bichuette, 2002 - Bichuette 2003; the loricariid Ancistrus cryptophthalmus Reis, 1987 - Trajano $\&$ Bichuette 2007). Visual censuses were applied to other species, such as the gymnotiform Eigenmannia vicentespelaea Triques, 1996 (Bichuette, 2003) and the heptapterids Rhamdiopsis sp. 1, from Chapada Diamantina (Mendes 1995; Bichuette unpubl. data) and Rhamdiopsis sp. 2, from Campo Formoso (Trajano \& Bockmann 2000), both in Bahia state. A significant variation among species, without taxonomic correlation, was observed for the estimated population sizes and densities, from very low (populations of ca. 1,000 individuals, densities $<0.1$ ind. $\mathrm{m}^{-2}$, not necessarily simultaneously) to relatively high, comparable to the observed for small to medium sized epigean populations (Trajano 2001, for a review). Ecological conditions, especially food availability, seem to be the main determining factors for population densities. Geographically restricted species might present relatively large populations if their density is high; conversely, species with low population densities may have large populations when widely distributed.

The Brazilian subterranean ichthyofauna is currently the best known throughout the world with regards to field ecology. Nevertheless, in view of its high taxonomic and ecological diversity, patterns are still unclear, and studies encompassing a larger number of species from different geographic regions are most desirable.

Since 1990, cavers of the Grupo Bambui de Pesquisas Espeleológicas - GBPE have dedicated to the exploration and mapping of several cave systems in the Serra do Ramalho, an important karst area in southern Bahia state, with several caves more than $10 \mathrm{~km}$ long (Rubbioli 1999, 2002). During these activities, the occurrence of several interesting animals was noticed and communicated to us. As a consequence, we joined some of these expeditions to the Serra do Ramalho and started to intensively investigate the subterranean fauna of some selected caves, as part of a project supported by FAPESP. Two troglobitic species, Rhamdia enfurnada Bichuette \& Trajano, 2005 (Heptapteridae) and Trichomycterus undescribed species (Trichomycteridae), and populations of non-troglomorphic fishes as well, have been found. As well, several invertebrates have been reported for this area, which assumes a place of major speleological importance among Brazilian karst areas (Bichuette \& Trajano 2004).

The ichthyofauna of epigean and hypogean streams in Serra do Ramalho was recently surveyed and a faunistic list produced for the area (Mattox et al. 2008). Likewise, a three-year study on the ecology of the large population of Rhamdia enfurnada was just concluded. We present here observations on natural history and population data for this and other, less abundant fishes found in caves from Serra do Ramalho.

\section{Materials and Methods}

The Serra do Ramalho karst area is situated in southwestern Bahia state, Middle São Francisco River basin (see map in Mattox et al. 2008: fig. 1). According to Köppen (1948), the climate is defined as tropical dry, "Aw" type, characterized by a dry winter (March to October) and an annual precipitation around $640 \mathrm{~mm}$ (Instituto Nacional de Meteorologia/INMET). The native vegetation of the region consists of Caatinga (mesophytic and xeromorphic forests), interspersed with Cerrado (savannah-like). Serra do Ramalho is dominated by a plateau formed by carbonatic (limestone) rocks of the Bambuí Group. This plateau extends for kilometers and forms large cave systems in the region, distributed in two sections, the lower plateau, to the south, and the upper plateau, to the north.

Troglobitic catfishes have been found in two cave systems in the Enfurnado karst area: Gruna do Enfurnado, type-locality and only known habitat for Rhamdia enfurnada, and Água Clara-Lapa dos Peixes system, home for the undescribed species of Trichomycterus. We concentrated our population studies on two localities, Gruna do Enfurnado and Lapa dos Peixes. These caves are subject to accentuated decrease in the water level along the dry seasons and flash floods in the rainy one, resulting in a strong seasonality in the ecosystems dynamics.

Gruna do Enfurnado ( $13^{\circ} 38^{\prime} 45,47^{\prime \prime} \mathrm{S}$ and $\left.44^{\circ} 12^{\prime} 7,11^{\prime \prime} \mathrm{W}\right)-$ with 7,560 $\mathrm{m}$ of passageways, it is one of the largest in the upper plateau. Two streams, one probably autochthonous (fed by subterranean water) and one allochthonous, cross respectively the distal and the proximal ends of the base-level conduit. These streams connect only during very heavy rains (not annually), when the water level increases dramatically and there is a water flow running in the large galleries between the two streams; most of the time, there are only discontinuous water pools in these galleries, some dozens of meters long, where catfish may be trapped and survive for long periods. The connections with the epigean drainage are unknown. Large amounts of organic matter as vegetal debris carried into the cave by floods are present in the cave, representing an abundant source of food for cavernicoles.

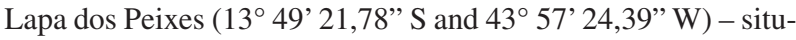
ated at the lower plateau, the Lapa dos Peixes has 7,020 $\mathrm{m}$ of mapped passageways, with a main conduit crossed by a temporary stream and some upper dry conduits, including a labyrinthic net of conduits upstream of the main entrance (the sinkhole) running parallel to the epigean main bed stream. At the distal end of this conduit net there is a small, $180 \mathrm{~m}$ long permanent vadose tributary fed by infiltration water and disappearing also by infiltration into the ground, where the troglobitic Trichomycterus catfish were found.

We concentrated our studies on Lapa dos Peixes and Gruna do Enfurnado, monitoring their ichthyofauna during the dry seasons of 2005, 2006 and 2007. The occurrence of flash floods prevents the continuity of the fieldwork during rainy seasons for safely reasons.

The study was based on ad libitum naturalistic observations (Sabino, 1999) and collections with hand-nets and, in some occa- 
sions, minnow traps (baited with bovine liver in a small nylon bag, preventing ingestion by the fish). Fish for identification and laboratory studies were killed by over-anesthesia in a solution of benzocaine, part was preserved in formalin 4\% (later transferred to ethanol 70\%), part in alcohol for tissue sampling.

For population studies, we used the mark-recapture method, with individual marking. In order to detect fish movements, we divided the streams inside Gruna do Enfurnado and the vadose tributary in Lapa dos Peixes into sections (Trajano 1997, Trajano \& Bichuette 2007), respectively $60 \mathrm{~m}$ long (total of 33 sections) and $20 \mathrm{~m}$ long (total of 09 sections); individuals captured in a given section were released, after marking, in the same section. A sharp decrease in the number of Trichomycterus specimens found in that tributary from 2005 on, in comparison to our previous observations in 2000 and 2003, hampered the population study. Therefore, we used visual censuses for this species (Table 1). Specimens of non-troglomorphic catfish were also marked and recaptured in this cave. Naturalistic observations from outside the water were made possible by its high transparency.

During the marking procedures, individuals slightly anesthetized in benzocaine were measured (standard length, SL, in $\mathrm{mm}$ ) to the nearest $0.1 \mathrm{~mm}$ with calipers, weighted (W, in $\mathrm{g}$ ) with dynamometer Pesola (precision varying according to the fish weight), marked and released after recovering from the anesthesia. Marking was done using subcutaneous visible implant tags (soft VIalpha tags, from Northwest Marine Technology, www.nmt-inc.com). The SL and weigh were used to calculate Fulton's condition factor $\left(K=100 \mathrm{WSL}^{-b}\right.$; Le Cren 1951). The power coefficient (b) for the growth equation was estimated from the slope of the regression of $\log$ weight on $\log$ SL.

\section{Results}

The large Rhamdia enfurnada population has been studied between 2005 and 2008 (two or three visits per year), and data analysis is in progress. More than 1,300 individuals were captured; ca. 850 out of 1,000 catfish captured until September 2007 were marked and released (ca. 160 were recaptured at least once until August 2008), the remaining catfish were either released without mark (too small for marking) or collected for laboratory studies, including genetics, behavior, physiology of pigmentation, morphology and diet. Maximum population densities of 10 ind. $\mathrm{m}^{-2}$, most juveniles and sub-adults (up to $100 \mathrm{~mm} \mathrm{SL}$ ), were observed in shallow places. The population was preliminarily estimated by visual censuses in 10,000+ individuals. In the cave habitat, adults are seen in the bottom, midwater and near the surface; juveniles were observed hiding under boulders. These fish swim slowly, exploring the environment continuously. The catfish are relatively sedentary, staying for several months or even years in $60 \mathrm{~m}$ long stream reaches; no individual was captured in a stream different from the one where it was marked. Growth occurs is pulses, with growth rates in rainy seasons markedly higher than in dry seasons (when many cases of negative growth were recorded). Detailed results will be published elsewhere.

Behavioral and physiological studies in laboratory are also in progress. When isolated, these catfish present low levels of activity, spending long periods (one hour or more) stationary. Agonistic interactions are rarely observed in collective tanks. Nevertheless, large individuals may become aggressive and eventually kill nearly-sized conspecifics maintained in the same tanks. We could not establish the factors leading to such occurrences yet, but the large size of the individuals involved indicate that they are related to sexual maturity.

The only other fishes found in Gruna do Enfurnado, with some dozens of individuals observed, are normally eyed and pigmented erythrinids, Hoplias group malabaricus (traíras), living in slowmoving water pools and some reaching large sizes. All individuals observed were in good physical condition, not emaciated and active; however, two large specimens captured had empty stomachs. Fish of different size classes were observed, including young ones. In some deep stream reaches (up to $1 \mathrm{~m}$ during the dry season) and pools, both catfish and erythrinids were observed. The traíra seems to be predator of large catfish $(300+\mathrm{mm}$ total lenght $)$ - several large catfishes collected in a lake at the distal end of the cave had signals of old bites and we observed freshly half-eaten catfish near a place where a very large traíra (400+ mm total lenght) was sitting.

In April 2000, cavers from the Bambui Speleological Association guided us to the small vadose tributary inside Lapa dos Peixes where troglomorphic catfishes had been noticed during exploration and mapping activities. On that occasion, we counted 15 specimens of Trichomycterus in the $180 \mathrm{~m}$ long stream. Seven catfish were collected for description. Small troglomorphic catfish, apparently the same Trichomycterus species, where also seen in a small side pool inside the Gruna da Água Clara, located about $5 \mathrm{~km}$ upstream the Lapa dos Peixes cave system, but no fish was captured due to difficulties of access to the pool, very slippery and muddy. Lapa dos Peixes was visited again in September 2003, and living specimens were brought to the laboratory for behavioral studies.

The numbers of fish recorded by visual censuses (including those eventually collected) in seven visits to Lapa dos Peixes are in Table 1. Troglomorphic Trichomycterus catfishes were seen throughout the cave stream, whereas normally eyed and pigmented Pimelodella and Rhamdia catfishes were always found upstream, at the distal end of the conduit (sections 7 to 9); tetra characins of the genus Astyanax, usually one or two individuals, were also found in that cave sector. The strong cryptobiotic and avoidance behavior of the Trichomycterus catfish, quickly hiding under stones and wall crevices when illuminated, rendered their capture quite difficult. The counts in Table 1 certainly produce underestimates of the population size in the Lapa dos Peixes vadose stream. However, considering that the observation methods were the same in all visits (two observers with spotlights walking slowly upstream), it is safe to conclude that this particular population had a significant decrease from 2000 to the present day, for reasons still unknown.

The condition factor calculated in 2005 for Pimelodella was: April $(\mathrm{N}=6)$, mean $=10.36 \times 10^{-6}$, varying from 8.82 to $11.90 \times$ $10^{-6}$; July $(\mathrm{N}=5)$, mean $=10.65 \times 10^{-6}$, varying from 8.24 to $12.77 \times$ $10^{-6}$; September $(\mathrm{N}=6)$, mean $=10.28 \times 10^{-6}$, varying from 7.86 to $11.43 \times 10^{-6}$. The fish were relatively small $(\mathrm{ST}=40.0$ to $67.8 \mathrm{~mm}$; the specimen collected in the main conduit - see below - was

Table 1. Number of catfish in the small vadose tributary in Lapa dos Peixes cave, Serra do Ramalho karst area.

Tabela 1. Número de exemplares de bagres no pequeno tributário vadoso da Lapa dos Peixes, área cárstica da Serra do Ramalho.

\begin{tabular}{|c|c|c|c|c|c|c|c|}
\hline \multirow[t]{2}{*}{ Species } & 2000 & 2003 & \multicolumn{3}{|c|}{2005} & 2006 & 2007 \\
\hline & April & September & April & July & September & April & September \\
\hline Trichomycterus sp. & 15 & 17 & 3 & 2 & 1 & 3 & 6 \\
\hline Pimelodella sp. & $5^{\mathrm{a}}$ & 2 & 10 & 5 & $6^{\mathrm{b}}$ & 1 & 1 \\
\hline Rhamdia sp. & - & - & $1^{\mathrm{c}}$ & $1^{\mathrm{c}}$ & $1^{\mathrm{c}}$ & - & - \\
\hline
\end{tabular}

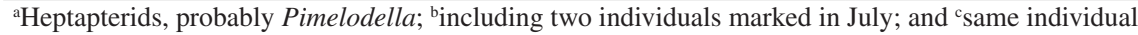


$73 \mathrm{~mm}$ long) and, like the observed for condition factor, the mean size did not vary between visits: April $=50.3 \mathrm{~mm}$, July $=56.8 \mathrm{~mm}$; September $=56.0 \mathrm{~mm}$. These fish were in relatively good condition. Two out of three specimens marked and released in July were recaptured in September (Table 1).

On the other hand, the single specimen of Rhamdia found in the cave in 2005, which was marked and recaptured twice, was very emaciated since its first capture (end of the rainy season, when food availability is higher), losing one third of its body mass and shrinking from April $(\mathrm{ST}=104.0 \mathrm{~mm}$; $\mathrm{w}=10.5 \mathrm{~g})$ to September $(\mathrm{ST}=$ $94.1 \mathrm{~mm} ; \mathrm{w}=6.8 \mathrm{~g})$.

\section{Discussion}

The single $R$. enfurnada population, preliminarily estimated in 10,000 individuals, is one of the largest among stream-dwelling troglobitic Brazilian catfishes, and certainly the largest among the cave heptapterids. Behavioral and physiological studies in laboratory indicate that these fishes are generally less active and present a less diversified repertoire of agonistic behavior than Pimelodella kronei, from the Upper Ribeira karst area, southern São Paulo state, the other Brazilian troglobitic Rhamdinii studied in detail (e.g., Trajano 1991b, Trajano \& Menna-Barreto 1995).

The permanence of individual erythrinds in the same sites during months or even years indicate that they are feeding, and possibly also reproducing in the cave, since small fish were also seen. This, allied to the apparent isolation of the subterranean drainage, indicates that these erythrinids may be troglophilic in the Gruna do Enfurnado. Erythrinids hypothesized as troglophilic have also been recorded in caves located in some other areas, such as the São Domingos karst area, state of Goiás, and Altamira-Itaituba sandstone karst area, state of Pará (Bichuette \& Trajano 2003). In spite of the rather unstable environment, subject to flash floods almost yearly, the ichthyofauna from Gruna do Enfurnado, basically composed by two species, a troglobitic and troglophilic one, is quite stable since the number of fish observed in consecutive years was fairly constant.

The occurrence of troglomorphic Trichomycterus catfish in the Água Clara Cave, apparently conspecific with those from Lapa dos Peixes, indicates that this species may be widely distributed throughout the inaccessible limestone fissures connecting these caves. We hypothesize that the population observed in the Lapa dos Peixes vadose tributary is a sink population, i.e., a population formed by migrants which, if cut off from the source of migrants, eventually becomes extinct (Fong 2004). The source population, characterized by an excess of production allowing it to continue to grow if isolated (Fong op. cit.), is somewhere else, perhaps in the inaccessible fractured phreatic habitat connecting Lapa dos Peixes, Gruna da Água Clara and possibly other caves in the area.

In opposition to the observed for the troglobitic Pimelodella spelaea (Trajano et al., 2004) and Trichomycterus itacarambiensis (Trajano 1996), which showed a significant decrease in the mean condition factor along the dry season, the non-troglomorphic Pimelodella catfish from Lapa dos Peixes did not seem to be subject to an increasing feeding stress during the dry season (at least for 2005).This data points to a quite stable, small group of sub-adults living during several months without much difficulty in the Lapa dos Peixes vadose tributary. Their near disappearance in 2006 and 2007 indicates that such group also represented a sink population, too small for self-sustainance. Therefore, it could not be considered as a troglophile, although the high potential for the subterranean life was apparent in their long permanence in the cave. Shrinkage of cave fish subject to extreme feeding stress was also reported for $P$. spelaea and T. itacarambiensis.
Bichuette \& Trajano (2004) stressed the relevance of the cave fauna from Serra do Ramalho karst area, where several troglobites have been found, many awaiting formal description, including, besides the catfishes Rhamdia enfurnada and Trichomycterus sp., a new relict species of Oniscidea isopod, genus Thailandoniscus, (Leila A. Souza, pers. comm.), new Hydrobiidae gastropods and planarians (pers. obs.) and two relictual arachnids which have been included in the Lista de Fauna Brasileira Ameaçada de Extinção 2002 - the harvestman Giupponia chagasi Pérez \& Kury, 2002 and the amblypygid Charinus troglobius Baptista \& Giupponi, 2002. Nevertheless, the Serra do Ramalho, characterized by extensive limestone outcrops and large cave systems, reaching up to $20 \mathrm{~km}$ (e.g. Gruta do Boqueirão), and representing an important faunistic corridor between the northeastern Goiás and Tocantins states and the southwestern Bahia state, is still under-explored in view of its high scientific potential. This region is not legally protected and is threatened by deforestation. This can lead cave populations to rapid extinction, because nutrients come basically from the surface, especially during floods between October and March. Protection actions are, thus, urgently needed.

\section{Acknowledgements}

We are most indebted to the students and biologists who helped with the fieldwork, especially Vanessa Felice, Ana Luiza Feigol Guil and Flávia Pellegatti Franco. This study was supported by the Fundação de Amparo à Pesquisa do Estado de São Paulo - FAPESP, Projeto Temático \# 2003/00974-5. ET is partially supported by the Conselho Nacional de Desenvolvimento Científico e Tecnológico CNPq (fellowship \# 302174/2004-4). Permission for collections was given by IBAMA (permissions DIFAP/IBAMA n 51 - 09/05/2006 and 151/2006-CGFAU).

\section{References}

BICHUETTE, M.E. 2003. Distribuição, biologia, ecologia populacional e comportamento de peixes subterrâneos, gêneros Ituglanis (Siluriformes: Trichomycteridae) e Eigenmannia (Gymnotiformes: Sternopygidae), da área cárstica de São Domingos, nordeste de Goiás. Tese de Doutorado, Universidade de São Paulo, São Paulo. 330 p.

BICHUETTE, M.E. \& TRAJANO, E. 2003. Epigean and subterranean ichthyofauna from São Domingos karst area, Upper Tocantins river basin, Central Brazil. J. Fish Biol. 63(5):1100-1121.

BICHUETTE, M.E. \& TRAJANO, E. 2004. Fauna troglóbia da Serra do Ramalho, Bahia: propostas para sua conservação. In Resumos do I Encontro Brasileiro de Estudos do Carste. [s.n.], Belo Horizonte, p. 20. Encontro técnico-científico da associação Redespeleo Brasil.

BICHUETTE, M.E. \& TRAJANO, E. 2007. Distribuição, ecologia e status de conservação de bagres subterrâneos da Chapada Diamantina, Bahia Central (Siluriformes: Heptapteridae). In Resumo expandido do II Encontro Brasileiro de Estudos do Carste. Universidade de São Paulo, São Paulo, p. 98-101. Encontro técnico-científico da associação Redespeleo Brasil.

FONG, D.W. 2004. Intermittent pools at headwaters of subterranean drainage basins as sampling sites for epikarst fauna. In Proceedings of the Symposium Held (W.K. Jones, D.C. Culver \& J.S. Herman, coord.). Karst Waters Institute, Shepherdstown, p. 114-188.

Le CREN, E.D. 1951. The length-weight relationships and seasonal cycle in gonad weight and condition in the perch (Perca fluviatilis). J. Animal Ecol. 20:201-219.

MATTOX, G.M.T., BICHUETTE, M.E., SECUTTI, S. \& TRAJANO, E. 2008. Surface and subterranean ichthyofauna in the Serra do Ramalho karst area, northeastern Brazil, with updated lists of Brazilian troglobitic and troglophilic fishes. Biota Neotrop. 8(4):145-152.

MENDES, L.F. 1995. Ecologia populacional e comportamento de uma nova espécie de bagres cavernícolas da Chapada Diamantina, BA (Siluriformes, 
Pimelodidae). Tese de Doutorado, Universidade de São Paulo, São Paulo. 86 p.

RUBBIOLI, E. 1999. O Carste. (Belo Horizonte, Grupo Bambuí de Pesquisas Espeleológicas) 11(1):1-24.

RUBBIOLI, E. 2002. O Carste. (Belo Horizonte: Grupo Bambuí de Pesquisas Espeleológicas) 14(4):141-284.

RUBBIOLI, E. 2004. Novas expedições na Serra do Ramalho: a Gruna do Enfurnado. O Carste, 16(2):52-57.

SABINO, J. 1999. Comportamento de peixes em riachos: métodos de estudo para uma abordagem naturalística. In Ecologia de peixes de riachos (E. Caramaschi, R. Mazzoni \& P.R. Peres-Neto, eds.). PPGE-UFRJ, Rio de Janeiro, p. 183-208.

TRAJANO, E. 1991a. Population ecology of Pimelodella kronei, troglobitic catfish from Southeastern Brazil (Siluriformes, Pimelodidae). Env. Biol. Fish. 30(4):407-421

TRAJANO, E. 1991b. Agonistic behaviour of Pimelodella kronei, a troglobitic catfish from Southeastern Brazil (Siluriformes, Pimelodidae). Behav. Proc. 23(3):113-124.

TRAJANO, E. 1996. Ecologia, comportamento e evolução de peixes subterrâneos. Estudo de caso: Trichomycterus sp. da caverna Olhos d'Água, Itacarambi, MG. Tese de Livre-Docência, Universidade de São Paulo, São Paulo. 83 p.
TRAJANO, E. 1997. Population ecology of Trichomycterus itacarambiensis, a cave catfish from eastern Brazil (Siluriformes, Trichomycteridae). Env. Biol. Fish. 50(4):357-369.

TRAJANO, E. 2001. Ecology of subterranean fishes: an overview. Env. Biol. Fish. 62(1-3):133-160.

TRAJANO, E. \& BICHUETTE, M.E. 2007. Population ecology of cave armoured catfish, Ancistrus cryptophthalmus Reis, 1987, from Central Brazil (Siluriformes: Loricariidae). Ecol. Freshwater Fish. 16(2):105-115.

TRAJANO, E. \& BOCKMANN, F.A. 2000. Ecology and behaviour of a new cave catfish of the genus Taunayia from northeastern Brazil (Siluriformes, Heptapterinae). Ichthyol. Explor. Freshwaters. 11(3):207-216.

TRAJANO, E. \& MENNA-BARRETO, L. 1995. Locomotor activity pattern of Brazilian cave catfishes under constant darkness (Siluriformes, Pimelodidae). Biol. Rhythm Res. 26(3):341-354.

TRAJANO, E., REIS, R.E. \& BICHUETTE, M.E. 2004. Pimelodella spelaea, a new cave catfish from Central Brazil, with data on ecology and evolutionary considerations (Siluriformes: Heptapteridae). Copeia. 2004(2):315-325.

Received 13/10/08

Revised 03/04/09

Accepted 20/03/09 
